\title{
Recent patents in automation in drug discovery
}

\begin{tabular}{|c|c|c|c|c|c|}
\hline Patent \# & Subject & Assignee & Author & $\begin{array}{l}\text { Priority } \\
\text { application } \\
\text { date }\end{array}$ & $\begin{array}{l}\text { Publication } \\
\text { date }\end{array}$ \\
\hline WO 200135072 & $\begin{array}{l}\text { Automated measurement of cell viability, involving } \\
\text { contacting cells with a luminescent reporter molecule, } \\
\text { imaging the cells to get signals, converting signals } \\
\text { into digital data, and using the data to measure viable cells. } \\
\text { The method provides high-content and high-throughput } \\
\text { screening that significantly improves target validation and } \\
\text { candidate optimization. }\end{array}$ & $\begin{array}{l}\text { Cellomics } \\
\text { (Pittsburgh, PA) }\end{array}$ & $\begin{array}{l}\text { Bellutta P, } \\
\text { Chen Y, } \\
\text { Debiasio R, } \\
\text { Ghosh RN, } \\
\text { Giuliano K, } \\
\text { Pasley JW }\end{array}$ & $1 / 18 / 2000$ & $5 / 17 / 2001$ \\
\hline WO 200134831 & $\begin{array}{l}\text { An assay for catalase in a test sample using a direct assay } \\
\text { for catalytic activity amenable to automation; useful } \\
\text { diagnostically as a biomarker of diseases or peroxisome } \\
\text { proliferation, or in screening new pharmaceuticals } \\
\text { and therapies. }\end{array}$ & $\begin{array}{l}\text { SmithKline } \\
\text { Beecham } \\
\text { (London; } \\
\text { Philadelphia, PA) }\end{array}$ & $\begin{array}{l}\text { O'Brien PJ, } \\
\text { Slaughter MR }\end{array}$ & 11/12/1999 & $5 / 17 / 2001$ \\
\hline WO 200123886 & $\begin{array}{l}\text { Predicting the in vivo cytotoxicity of a candidate compound, } \\
\text { comprising measuring indicators of cellular health at different } \\
\text { concentrations of the test compound; useful for identifying } \\
\text { and designing new therapeutic agents with limited } \\
\text { cytotoxicity, and in drug manufacture and dosing. }\end{array}$ & $\begin{array}{l}\text { Pharmacia } \\
\text { \& Upjohn } \\
\text { (Kalamazoo, MI) }\end{array}$ & $\begin{array}{l}\text { Cockerell GL, } \\
\text { McKim JM }\end{array}$ & $6 / 2 / 2000$ & $4 / 5 / 2001$ \\
\hline WO 200111358 & $\begin{array}{l}\text { Monitoring a target substance in a biological system, which } \\
\text { involves labeling the target substance with apo metal-binding } \\
\text { protein and measuring the signal emitted; useful for } \\
\text { determining the cytotoxicity of a drug of interest. The method } \\
\text { is applicable in high-throughput testing or evaluation devices, } \\
\text { and is amenable to automation. }\end{array}$ & $\begin{array}{l}\text { Tibotec } \\
\text { (Mechelen, } \\
\text { Belgium) }\end{array}$ & $\begin{array}{l}\text { de Kerpel JOA, } \\
\text { Dierynck I, } \\
\text { Pauwels RWJ, } \\
\text { Roelant CHS, } \\
\text { van Acker KLA }\end{array}$ & 8/6/1999 & $2 / 15 / 2001$ \\
\hline WO 200079241 & $\begin{array}{l}\text { An automated method for identifying compounds modulating } \\
\text { macromolecule trafficking through endosomes. The method } \\
\text { uses digital data obtained by converting a luminescent signal } \\
\text { from cells contacted with the compound. }\end{array}$ & $\begin{array}{l}\text { Cellomics } \\
\text { (Pittsburgh,PA) }\end{array}$ & $\begin{array}{l}\text { Dunlay RT, } \\
\text { Ghosh RN, } \\
\text { Giuliano KA, } \\
\text { Gough AH, } \\
\text { Rubin RA }\end{array}$ & 12/13/1999 & $12 / 28 / 2000$ \\
\hline US 6046002 & $\begin{array}{l}\text { Methods for identifying gene products that mediate a pheno- } \\
\text { type (e.g., drug resistance or sensitivity) and new bioactive } \\
\text { compounds; comprises detecting the growth differences } \\
\text { between host cells that differ in target gene product dosage. } \\
\text { The method is useful in identifying the gene product, system, } \\
\text { or pathway affected by a drug, as well as for identifying drugs } \\
\text { having activity against target gene products. }\end{array}$ & $\begin{array}{l}\text { Stanford } \\
\text { University } \\
\text { (Stanford, CA) }\end{array}$ & $\begin{array}{l}\text { Davis R, } \\
\text { Giaever GN, } \\
\text { Shoemaker D }\end{array}$ & 1/5/1998 & $4 / 4 / 2000$ \\
\hline WO 200013651 & $\begin{array}{l}\text { A method for screening parathyroid hormone compounds for } \\
\text { potential use as drugs for treating, for example, osteoporosis } \\
\text { or osteopenia, by determining the change in reporter gene } \\
\text { expression in cells expressing parathyroid hormone receptors. } \\
\text { The screening method is simple, sensitive, and suitable } \\
\text { for automation. }\end{array}$ & $\begin{array}{l}\text { Aventis Pharma } \\
\text { (Strasbourg, } \\
\text { France) }\end{array}$ & $\begin{array}{l}\text { Crumley GR, } \\
\text { Labaudiniere RF, } \\
\text { Morse CC, } \\
\text { Yu KT }\end{array}$ & 9/4/1998 & $3 / 16 / 2000$ \\
\hline WO 9966324 & $\begin{array}{l}\text { Novel energy transfer systems for assaying protein inter- } \\
\text { actions, enzyme activities, and the concentration of analytes } \\
\text { or signaling molecules; can also be used for drug discovery, } \\
\text { drug screening, to detect changes in protein-protein inter- } \\
\text { action, and in functional genomics to determine the } \\
\text { cellular function of a gene. }\end{array}$ & $\begin{array}{l}\text { Biosignal Packard } \\
\text { (Montreal, PQ, } \\
\text { Canada), } \\
\text { Vanderbilt Univ. } \\
\text { (Nashville, TN) }\end{array}$ & $\begin{array}{l}\text { Johnson } \mathrm{CH} \text {, } \\
\text { Joly E, } \\
\text { Piston DW }\end{array}$ & 6/16/1998 & 12/23/1999 \\
\hline US 5994061 & $\begin{array}{l}\text { A simple, rapid method for screening for drugs that increase } \\
\text { expression of the apolipoprotein Al gene, which may then be } \\
\text { useful for treating coronary artery disease. }\end{array}$ & $\begin{array}{l}\text { Queen's Univ. } \\
\text { (Kingston, ON, } \\
\text { Canada) }\end{array}$ & $\begin{array}{l}\text { Tam S, } \\
\text { Zhang X }\end{array}$ & 9/29/1995 & 11/30/1999 \\
\hline DE 19815078 & $\begin{array}{l}\text { A method for the preparation of aromatic or heteroaromatic } \\
\text { Grignard reagents that are useful as drug intermediates, } \\
\text { preferably in carrier-bound form to automate and simplify } \\
\text { the production of combinatorial libraries. }\end{array}$ & $\begin{array}{l}\text { BASF AG } \\
\text { (Ludwigshafen } \\
\text { Germany) }\end{array}$ & $\begin{array}{l}\text { Boymond L, } \\
\text { Cahiez G, } \\
\text { Knochel P, } \\
\text { Rottlaender M }\end{array}$ & 4/6/1998 & 10/7/1999 \\
\hline
\end{tabular}

Source: Derwent Information, Alexandria, VA. The status of each application is slightly different from country to country. For further details, contact Derwent Information, 1725 Duke Street, Suite 250, Alexandria, VA 22314. Tel: 1 (800) DERWENT (info@derwent.com). 